\title{
Hedgerows and Petticoats: Sartorial Subversion and Anti-enclosure Protest in Seventeenth-century England
}

In seventeenth-century England, farmers and rural labourers contested authority through rituals of protest drawn from traditional communal practices. The ritual shaming of authorities or neighbours through skimmingtons involved cross-dressing and allowed for expressions of frustration and repression to manifest themselves in this festive practice. When protesting against the enclosure of common lands in southwest England, a man taking on the role of Lady Skimmington put 'ritual and festive inversion to new uses'. ${ }^{\mathrm{I}}$ Although a typical skimmington was directed against a fellow member of the community, during the Western Rising of 1626-32 Lady Skimmington and her followers directed their discontent against outsiders and social superiors, specifically King Charles I for enclosing their forests and the wealthy urbanites who were granted that land. Dressed in women's clothing, John Williams alias Lady Skimmington became a symbol of disorder to the state and a symbol of justice to members of the rural communities affected by enclosure. Women occasionally dressed in men's clothing and adopted male titles, such as captain, to protest enclosure and their own perceived injustices. Since women did not have an acceptable sphere for cross-dressing, such as in a skimmington or on stage, cross-dressing women were more threatening to the state. Cross-dressing provided a battleground for the contestation between individuals, communities, and the state over the ownership of land, one's social and gendered identity, and even ownership of the title Lady Skimmington. The conflict over ownership in its many forms, played out in the large scale protests against enclosure, was also reflected in the theatre, including The Late Lancashire Witches, The Tamer Tamed, and The Roaring Girl. Cross-dressing engaged the struggle to determine ownership of property, gender identity, and social status in ways that challenged and upheld traditional hierarchical society. 
Skimmington has a long history in England and a strong tradition in the West Country. Skimmington or to 'ride skimmington' was a dramatic procession of public humiliation of and reprisal against a trespasser of communal norms. The most common focus of a skimmington was a woman as a shrew, a scold, or a husband-beater - someone inverting social order. Evolving over the centuries and adapted by region to specific instances, skimmington targets shifted from local thieves and charlatans in the Middle Ages to more specific gender criminals such as adulterers, scolds, and even witches in the mid-sixteenth century. Later in the I700s men were increasingly targets of skimmingtons for social crimes such as wife-beating. ${ }^{2}$ Evidence demonstrates that skimmingtons perservered in the West Country well into the nineteenth century, a testament to the depth of its cultural roots. ${ }^{3}$ A protest skimmington involving male cross-dressing distinctly emerged in the early I6oos. 4 The festive culture from which skimmington derived created a tie that bound communities and community members together. It provided a discourse and vocabulary through which they could express their outrage, anxiety, and understanding of justice. In the I630s the fictional character Lady Skimmington, in his costume of women's clothing, led a call to assemble community dwellers for the disassembly of the fences and enclosures in the Forests of Dean and Braydon.

Cross-dressing allowed for the performance of a class and gender other than the one given by birth. The public performance of social rank played an important part in Elizabethan and Stuart society. Visibility was integral in maintaining power and authority — punishments were public and humiliating; processions were grand and ritualized. The theatricality of power and authority dictated one's place in society through the kind and quality of dress. The cross-dresser could re-appropriate this power to mock authority. Popular literature about cross-dressing and unruly women, particularly tracts like The Cruell Shrew Or, the Patient Man's Woe (I6IO), Hic Mulier (1620), and Haec $\operatorname{Vir}(\mathrm{I} 620)$ addressed the place of women and the performance of gender as it related to the continuation of well ordered society.5 In the Bible, gender is the oldest and strongest marker of immutable difference because cross-dressing for men and women alike was 'an abomination to the Lord'. William Prynne's tract against cross-dressing used Deuteronomy to claim 'If then a woman's putting on or wearing of man's apparel ... incurres an anathema ... doth not a man's attiring himself in woman's vestments ... much more demerit?' 6 Prynne drastically interprets the verse to justify a more severe hierarchy of divinely created difference. While the woman's transgression is severe, the man's loss of 
masculinity is a greater sin. Many contemporaries wondered if cross-dressing signaled larger social and moral corruption. Cross-dressing could also raise uncomfortable questions about other incongruous but acceptable gender performances, such as a female monarch and an effeminate king.

The seventeenth century provides a locus for anxieties over clothing, gender, and identity. Perhaps strong identification with the monarchy shaped and stirred these male-female power questions in the subjects of Elizabeth and James. Rumours of James's extravagance, effeminacy, and homosexuality followed the long and successful reign of a female monarch, who also worked to fashion her gender and power in a way that both challenged and upheld the traditional hierarchy. Gender confusion and controversy in the period I570-1620 stemmed in part from the 'reigns of a manly queen and a queenish king'.7 The 'sex-and-gender role[s]' for both Elizabeth and James were 'under intense scrutiny'. ${ }^{8}$ These social and political pressures may have influenced the emergence of male cross-dressing as a form of protest in the early seventeenth century.

Lady Skimmington intersects with the popular dramatic device of crossdressing and with a general concern over the nature of masculinity and femininity. Cross-dressing characters were common in Renaissance theatre as a comical and dramatic device. On the stage, actors playing men in women's clothing could pursue illicit desires. Male actors playing women dressed as men could defend lovers and family through the manipulation of already tenuous boundaries of order, self, and gender. These plays ultimately did not disrupt the 'natural' and larger order of society because the female characters were often restored to their proper place and the men were appropriately punished for their transgression. Public theatre gave rise to fears of effeminacy and questions about the nature of masculinity. Laura Levine in Men in Women's Clothing posits that masculinity had to maintain its existence through its performance since femininity seemed to be the 'default' gender. David Cressy, however, argues against the idea that cross-dressed male dramatic characters were degraded; instead he finds that the transvestite male was more 'energized than emasculated'. 9 On stage, the cross-dressed man could outwit and humiliate his opponent; he could laugh at the opponent's defeat by a 'woman' without challenging the gender hierarchy because beneath the dress he was still a man. The men who called themselves Lady Skimmington were able to outwit and humiliate the authorities in much the same manner.

Within the context of the enclosure riots, cross-dressing engaged the power of clothing to enhance the impact of destroying property while sub- 
verting the gender hierarchy. Protesters could cross-dress in three ways to oppose enclosures: as men dressed as women to take part in a skimmington; as women dressed as men (a more threatening social inversion); or through state-imposed punishment of women's clothing on men on the pillory. The state used its hegemonic understanding of a natural social order to claim that protests against enclosure were unnatural and therefore invalid. Inversion protests exposed the state view as a constructed social network equally unnatural and no more significant than peasants' own claims. Festive inversion 'demonstrated a contrast between the hidden and the manifest, the pri-

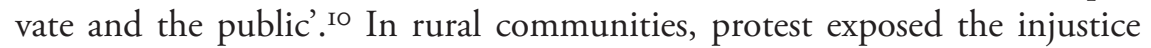
of enclosure hidden behind royal prerogative. For the state, enclosure manifested the economic potential of common land. Both the rural labourers and the state used clothing as a way of asserting their understanding of cultural values, order, and justice.

Within a village community, commonly used land was a combination of manorial waste land, manor lands after the harvest, forests or unowned land. Common land supplemented the income of poor villagers by serving as a place to glean, graze their few animals, hunt, fish, or collect timber for housing and heat. Enclosure physically barred people from using land as they had for generations; now neighbours trespassed where before they had rights of way. Freedom for rural labourers came through the practice of tradition - those unquestioned and often unwritten customs from time immemorial which bound the community together and provided a space for local definitions of rights and justice. ${ }^{I I}$ Enclosure criminalized the practice of these traditions. Trespassing is the crux of cross-dressing as a form of protest. Cross-dressing involves trespassing outside one's assigned social identity and was threatening because 'that station was in theory providentially determined and immutable.' ${ }^{\text {I2 }}$ Cross-dressing threatened the immutability of social station; so too, enclosure seemed to violate ancient laws which served the community and acted as a form of political protection for the more vulnerable in society. ${ }^{13}$

Ownership and use of land, like clothing, created distinctions among people because the value and type of a person's property, like a person's dress, conferred value onto that person. Sumptuary laws illustrate the intertwined nature of station, ownership, and clothing. These laws responded to concerns that social chaos would follow on the heels of sartorial equality. Although Elizabethan sumptuary laws were repealed under James, the Jacobean period witnessed unflagging efforts to restore this very visible sign of social and sexual distinction. ${ }^{\mathrm{I} 4}$ James entered the growing controversy over whether cloth- 
ing determined one's gender identity when he denounced cross-dressing, expressing particular anxiety about the social impact of women's cross-dressing. According to Marjorie Garber, 'transvestism was located at the juncture of "class and gender" and increasingly through its agency gender and class were revealed to be commutable, if not equivalent'. Is This same conjunction was at the centre of a persistent underlying fear caused by enclosure rioters. Enclosure riots implied the concomitant destruction of social distinctions and physical barriers. An undifferentiated society could result in England's ruin, and an Englishman's financial ruin could come from the bills that accompanied increasingly extravagant sartorial displays. Sinful pride in one's attire harmed the community at large and enclosure, it was argued, was sinful when it depopulated villages. The homelessness created by the sin of enclosure provided a parallel for the sin of valuing clothing above all else.

John Taylor's poetry from the period evokes such comparisons. The following passage, for example, indirectly references the traditional use of manorial and common lands.

One man now in garments he doth wear

A thousand akers on his back doth beare

Whose ancestours in former times did give

Meanes for a hundred people well to live

Now all is shrunke, (in this vaineglorious age)

T'attire a coach, a footman, and a page. ${ }^{16}$

From time immemorial gleaning, fishing, and grazing privileges were a part of the tenant farmer's agreement with the lord of the manor in exchange for the tenant's labour. The 'thousand akers' provides a general image that can be applied to a specific change in the countryside. Through enclosure, acres of commonly used manorial land became an important source of income for absentee landlords whose expenditures and interests were increasingly urban and frivolous, as Taylor suggests:

To wear a farm in shoe-strings edged with gold

and spangled garters with a copyhold:

A hose and doublet, which a lordship cost

a gaudy cloak (three manor's price almost)

A Beaver, Band, and Feather for the Head

(Priz'd at the Churches tythe, the poor mans bread) 
For which the wearers are feared and abhorred

Like Jereboam's golden calves adored. ${ }^{17}$

A copyhold provided the only formal rights of tenant farmers to use common land and underutilized manorial wastes. Taylor's poetry alludes to larger shared concerns about English values; Taylor's image of wearing a copyhold on one's garters connects traditions of the past and the degrading pursuits of Taylor's contemporaries. He did not hide his contempt for the exchange of livelihood for status.

With regard to the common use of land, two systems of value were in conflict - the hegemonic concept of accumulating wealth and the subordinate concept of communal obligation between landlord and tenant. In response to this conflict and injustice communal outrage took the shape of a skimmington, whose leader clad in female garb could raise the call to rebellion. Communal obligation depended on the long-standing hierarchical relationships that stabilized society. Conflicts regarding the nature and extent of communal obligations wove a common thread through many plays of the early Stuart era. ${ }^{8}$

The popular and politically reactive comedy The Late Lancashire Witches (I634), for example, reverses each hierarchical relationship in the Seely family: father/son, mother/daughter, children/servants. Mall Spenser, a witch, curses the manservant's marriage to the maid, making the husband impotent and his wife a violent shrew. A skimmington both celebrated and mocked marriage insofar as within the ritual, the wife might beat her spouse for failing to perform sexually. According to Anthony Dawson a skimmington on the early modern stage is 'unambiguous' as a 'chief theatrical emblem ... it fixes the ridicule.' 19 Like a skimmington, the witch was a 'contained danger' who provided commentary on the inverted and unnatural hierarchy of wife over husband, children over parents, servant over master. With her gift of magical points Mall Spenser curses the servants' wedding and marriage, but the servants also transgress because they lord above their master's children. Both the witch and the skimmington punished such social inversions and communal transgressions. The witch provided a commentary on human hypocrisy that resembled a skimmington's message. Unlike witchcraft, the skimmington was a legitimate form of community protest. In the play, the witch's power misdirects the attention of the skimmington onto her victims. By undermining the skimmington as communal cure for social inversion, the witch further disrupts social order. Such inversions and the political commentary on that 
inversion intensify when Lawrence, the impotent husband, defeats Lady Skimmington in a brawl and his wife Parnell defeats the male Skimmington figure in a prolonged battle:

Enter [a] drum[mer] beating before a skimmington and his wife on a horse [followed by] diverse country rustics. As they pass, Parnell pulls [the] skimmington off the horse and Lawrence [likewise the] skimmington's wife, [and] beat them. [The] drum[mer] beats an alarm [and the] horse comes away. The hoydens at first oppose the gentlemen, who draw [their swords, at which] the clowns vail bonnet. [They all] make a ring [while] Parnell and [the skim[mington] fight. ${ }^{20}$

Arthur (a young land-owning gentleman) and Doughty (a land-owning yeoman and self-proclaimed witch-hunter) approve of both Lawrence and Parnell's fight against the skimmingtons and the skimmingtons' efforts to protect the community. The social inversion and communal transgression are reversed here; the community is punished for attacking the newly-weds who are themselves attacked by a witch. The point is not to punish the victims but to locate and eradicate the real source of the problem, as this couple does later when they burn the magic points and find that they have returned to normal as a loving couple. So, the community does not always know what is best, and the skimmington ride in this play attacks only the obvious cause not the underlying one. Doughty, as the community representative, thanks the skimmington riders and gives them tips for a drink at the tavern, restoring face to the community even though its attack was misdirected. ${ }^{2 I}$ Real skimmingtons also attacked the obvious cause of enclosure - the workers and owners and destroyed fences and hedges but could not attack enclosure's underlying causes - capitalist influences and changing royal and parliamentary regulations. These larger forces at work in the enclosure acts could not be dispelled as easily as they are in the play through uncovering witchcraft

The Western Rising (I626-32), a series of anti-enclosure riots, incorporated two aspects of cross-dressing - as community protest and as state punishment. In the Forest of Dean in Gloucestershire and the Braydon Forest in Wiltshire, leaders of the riots dressed in women's clothing and took the name Lady Skimmington. In Wiltshire, riot leaders were forced to dress as women on the pillory as punishment for their crime. The Western Rising led to government fears of spreading social and political upheaval, despite the focused and local nature of the riots. The state and local authorities viewed uprisings with a consistent mix of acknowledgment and fear. ${ }^{22}$ Sheriffs were 
under increasing pressure to end the riots and apprehend the leaders but in several instances soldiers joined the large numbers of organized and armed protestors and sheriffs were forced to retreat. ${ }^{23}$ The size and scale of these riots made the isolation and punishment of individual perpetrators more difficult and more pressing for the state; state officials focused on the leaders, many of whom took the alias of skimmington and the apparel of women to represent the outrage of their communities.

Forests were a source of royal revenue and Charles I increasingly 'exploited the forests' to raise the money parliament denied. ${ }^{24}$ The king made efforts to recognize local use of and rights to the forest but it was clear that deforestation was never up for negotiation. By I627 the attorney-general took action to identify who could legally claim common rights. The following year, royal decree formally 'extinguished' all claims to common rights within the areas to be enclosed. ${ }^{25}$ Once deforestation had taken place the king granted the partially enclosed forest, about 3,000 acres, to 'courtiers and government officials'; 'copyholders and freeholders' could claim common rights on the 17,000 remaining outlining acres. ${ }^{26}$ It was not the deforestation but the enclosure of the forest to non-local leaseholders that caused the outrage and riot. Local people still expected to live on and from the land while the king exercised his right to take what he wished from the same forest. The Gillingham rioters told the sheriff that they would not disband because 'here were we born and here we will die'. ${ }^{27}$ The forest, so important to both the crown's fiscal and physical authority and the general livelihood of its denizens, was the battleground between formal law and feudal rights of obligation to the poorer sort. The forest communities maintained their own economy outside capitalist tendencies and stood as a 'concrete sign of communal justice and resistance'. ${ }^{28}$ On 25 March 163I riots broke out in the Forest of Dean - about 500 people led by men dressed in women's clothing assembled to destroy the enclosures. The success of this riot and the potent presence of skimmington brought six times the number of people the following month. On 5 April, 3,00o people assembled to destroy the enclosures, fill ore pits, and damage houses in other parts of the forest. By the end of the month all the enclosures that had been part of the decree extinguishing common rights had been destroyed. ${ }^{29}$

Within a month an estimated I,ooo people participated in the Braydon Forest riots from May to June. Dressed again in women's clothing the riot leaders made threats against the home, workmen, and agent of Phillip Jacobsen, the new owner of the enclosed deforested area. By July, the rioters moved to a neighbouring forest, Chippenham, to foment further unrest. On 2I July I63I 
the seven men named in a 'commission of rebellion issued by Star Chamber' for the destruction of enclosures in the Chippenham were also suspected in the Braydon Forest riots. ${ }^{30}$ While unenclosed land on the outskirts continued to be available for tenant farmers and rural labourers, discontent remained for years after the Western Rising and people persisted in driving animals through the traditional but now closed paths. The continued destruction, although far less extensive than in the riots of the Western Rising, marked the locals' refusal to accept the exclusion from traditional lands imposed from outside their community.

In the Forest of Dean and Braydon Forest riots 'Lady Skimmington' was used both as an alias for the leaders and as a call to protest. State emphasis on the dangers of the skimmington and its recurrence in the Western Rising illustrate the power and presence that cross-dressing added to the acts of physical destruction. Since the Skimmington character provided a focus for the rioters and the government, the countrymen and sheriffs seemed to have little trouble putting a name, John Williams, to the man behind Lady Skimmington. The courts, however, did not see that Lady Skimmington was an identity with communal ownership. Not one man, but many men claimed the title and assumed the costume (not her). Either out of ignorance or disregard, the state focused on Skimmington as one man, believing and fearing his responsibility in every riot. The government was so concerned that it sent the 'undersheriff' with 'I2o men' to capture one man - Williams alias Skimmington. ${ }^{3 \mathrm{I}}$ When Williams was finally arrested and sent to Newgate Prison in London, his captor found himself in danger of attack from outraged villagers. The privy council had to provide a guard any time he entered the forest. Attacks on the man who captured Skimmington attest to the ability of representation to encapsulate the community's desires and frustrations.

On I2 June I635 the Braydon Forest rioters were sentenced. Fined the tremendous sum of $£ 500$ each, the leaders were placed on the 'Pillory at the Assizes in Womens Clothes as they were disguised in the Riots'. ${ }^{32}$ Cross-dressing, a tool of protest, became in state hands a form of punishment to shame the would-be shamers for inciting disorder. The remaining rioters on trial were fined lesser amounts and had to promise not to disturb future enclosures. With most of the riot leaders captured, the leader labeled 'Skimmington' received the heaviest fine. Punishment took the form of public deterrent; the state re-appropriated the representation of skimmington as a form of humiliation to reassert its power and authority as master, father, and husband of the people. Clothing used as punishment literally and figuratively made the 
men submissive to the will of the state rather than the will of the community which supported them.

Upon close investigation it appears that riots in the Forests of Braydon and Dean were led by two different men named John Williams and 'only the latter used the alias Skimington'.33 John Williams alias Skimington had been falsely accused of agitating 'anti-enclosure riots in Gloucestershire in June of I63I' where rumours circulated that 'Skymingtones leiuetenaunte and some fyve more of his company' came to destroy enclosures. 34 Of the men brought before the court in the incident, it was discovered, no skimmington was involved. Later that same year reports made to the privy council falsely indicated that riot leader Hoskins, who was never captured, was 'urging "Lady Skim[m]ington" and "her" followers to riot in Gillingham forest'. 35 Skimmington donned the petticoats of protest and his success in destroying the Forest of Dean enclosures continued to be a powerful symbol of the title and attire attached to this customary figure.

According to the records, it seems that no more than seven men crossdressed out of the thousands who participated in the Forest of Dean and Braydon Forest riots but the alias Skimmington repeatedly makes its way into the court documents. The state's central concern was the search, capture, and prosecution of Skimmington. Naturally the state would be most concerned about capturing the leaders but the preponderance and emphasis on the alias Skimmington, inaccurately applied in most cases, expressed the anxieties of a state experiencing one subversion too many through the dissolution of physical, legal and gendered boundaries.

Expressions of subversion also drew on the prevailing understanding concerning the nature of women, who were believed to be weak in reason and apt to be disorderly. Many believed married women were lawless because, as femmes covertes, they belonged to their husbands and could act without culpability under the law as non-citizens. Contrary and commonplace beliefs about women's nature and their accountability under the law shaped the approach to leveling enclosures and were a challenge for authorities to adequately dispel. In 1605 the Star Chamber ruled that if a woman offend in trespass, riot, or otherwise and an action is brought against her and her husband, the husband is answerable notwithstanding the action was without his privity'. ${ }^{36}$ The Star Chamber worked to combat the myth that women were above the law and placed women instead below their husbands, culpable but not in their own capacity - whether or not their husband, father, or master was involved in protest he would be brought to trial and punished alongside 
her. At the same time, transgressing hierarchy through clothing was a crime for which husbands were less accountable but perhaps more humiliated. William Lambarde, author of Eirenarcha, or the Office of Justice of Peace, stated that 'sundry women were punished in the Star Chamber, and that worthily: because putting off that shamefastnesse which beseemeth their sexe they arrayed themselves in the attire of men, and (assembling in a great number) they most riotously pulled down a lawfull inclosure'. ${ }^{37}$ Cross-dressing layered the effect of destruction and intensified the state's response. The context of Lambarde's condemnation of cross-dressing suggests a reason for women to cross-dress - to gain legitimacy through full culpability under the law. Prior to his recollection of women cross-dressing Lambarde states, 'if a number of women ... do assemble themselves for their own cause, this is no unlawful assemblie punishable by these Statutes: But if a man of discretion cause them to assemble to comit an unlawful act, then it is otherwise'. Lambarde makes no mention of punishing the husbands or fathers of the women who dressed as men to pull down enclosures.

Women and cross-dressing in riots serve as reminders that patriarchal ideals could never be achieved because those ideals conflicted with reality. Patriarchal ideals, however, provided a space for negotiation between women's actions and the law. John Walter finds that women's participation in riots was part of the way they manipulated the failings of formal law to recognize women as fully capable beings. Through riots women 'turn[ed] their marginal relationship to the structure of power within the community ... to their temporary advantage'. ${ }^{8}$ Natalie Davis notes that 'sexual inversion also gave more positive license to the unruly woman: her right as subject and as mother to rise up and tell the truth'.39 Women's participation in protests allowed them to challenge the law in a way that fit with women's roles as mouthpieces, even when those roles could earn a scold's punishment.

Women who chose to dress as men to destroy enclosures seem to contradict the logic of women's unaccountability. Their actions beg the question, why dress as men? Whereas cross-dressing men have a long history of taking part in these festive practices, women did not typically cross-dress because to do so would defeat the customary purpose of inversion. As Davis states, 'Real women in early modern Europe had less chance than men to initiate or take part in their own festivals of inversion'. ${ }^{\circ}$ Women who cross-dress to protest represent another form of re-appropriation distinct from male cross-dressing. Cross-dressing adds a new dimension to the very focused destruction of prop- 
erty, and such instances of women's cross-dressing are inadequately explained by peasant culture alone.

Female cross-dressers made noteworthy appearances in Tudor-Stuart England. While female cross-dressers in Shakespearean plays were often strong and admirable, a woman who cross-dressed in reality was guilty of the worst womanly vice - she was viewed as a whore and was in the seventeenth century increasingly arrested for prostitution. ${ }^{\mathrm{II}}$ Based on the true story of Mary Firth, The Roaring Girl combined the presence of female cross-dressing on stage and off. The main character Moll cross-dressed not to disguise herself but to loose herself from social female constraints. ${ }^{42}$ Women's freedom to claim personal rights as Moll did was also evident in a female-led enclosure riot in 1602 . Captain Dorothy Dawson and her fellow rioters were questioned by the Star Chamber for their participation in the destruction of enclosures in the Yorkshire valley of Nidderdale. While most women used the legal system's ambiguities and patriarchal dictates of female frailty as a defense - they were fighting for their husband's rights — one woman, Alice Mitchell, stated that 'the women had broken the fences in order to maintain "their Rights of common". 43 This unusual assertion of female political autonomy, although not the most beneficial in the court room and rarely documented, did exist. Women's active participation in the violent and widespread Midland riots of I607 is loosely paralleled in John Fletcher's The Tamer Tamed (written I609), which was censored for siding with the Levellers in the enclosure resistance. History records at least two cases in which female leaders took the title of Captain, just as Fletcher's Bianca does. In The Tamer Tamed the women's resistance centres on newlywed Maria who prevents the consummation of her marriage until her husband, Petruccio, is subdued and listens to her demands. Maria, Livia (Maria's sister), and Bianca (their cousin) lock her husband out of the bedroom and dress in breeches to protest the exploitative and violent nature of wife-taming husbands. The barrier between Maria and her husband proves more than a locked door: the breeches she puts on assert an equality between them and grant validity to the wife's demand to be heard. Within the limited places available to her, Maria determines the space of contestation, power, and ownership. Enclosed in pants and surrounded by other women, including 'Colonel Bianca', Maria makes her body her own property. 44

In these cross-dressing scenes, Fletcher draws on contemporary conflations of women's (enclosed) body with (enclosed) land. Enclosing hedges were, in the words of one poet, the 'girdling [of] a county'.45 The image of a girdle delineating spaces of private ownership placed a strict and feminized bound- 
ary on the land; it separated her, elevated her, and made her off limits to all but her 'husband' - her owner. Claims to tradition were increasingly met by strong derision of peasant customs. Adam Moore's Bread for the Poor and Advancement of the English Nation written in 1623 and published in 1653 , for example, finds the call to custom a hindrance to enclosure and therefore to improvement for the benefit of all England. Privatizing land through enclosure meant improving the nation and its people; those who disagreed would condemn England and its people to suffer. Farmers had a very different sense of common lands, claiming that the tenant and the land were 'all incorporate and bec[a]me one body' and likening the commons to a wife and helper. Moore distorts this personification of the land by shaming the farmer's treatment and protection of the land figured as spouse. If the land was the farmer's spouse, Moore asks farmers, 'why are you so cuckolded by Foreigners and strangers (while you make [commons] a prostitute to every lust) how can you help it? Were it not better therefore and more secure to take her home to your chamber and keep her with a guard where she cannot be abused?' 46 Just as the proper husband must protect his wife, the proper owner must protect his land. Moore inverts the customary view of land to shame the farmers, playing on implicit assumptions about the value of a woman's virginity and chastity. By using this long held traditional concept, he hoped to persuade the farmers that land, like a woman, was valuable when owned by only one man. In this way Moore uses one custom to undermine another.

The analogous relationship between women and land further explains why cross-dressing enhanced enclosure protests. If clothing signals gender and if women are homologous to land, then men who protested the loss of their land by dressing as women provided a physical referent for their political argument. A man gained power from becoming Lady Skimmington because when he donned a dress he was wearing the land on his body and making it his own. If a woman protested in man's clothing, however, did male ownership become hers? To be female, whether as woman or as land, was to be possessed. As in The Tamer Tamed, women who put on men's clothing became a double threat, in that the distinction between woman as possession and woman assuming the rights of a male possessor became indiscernible, or so the state feared. The desire to separate possession and possessor as female and male respectively is evident in the writings of both Lambarde and Moore. Their discussion of law and enclosure uses the familiar references of women as possessions and land as feminine to argue for the continued subjugation of women to men and land to land owners. 
For rioters, Lady Skimmington's leadership provided the framework for a lawful lawlessness - an open space for dissenting non-hegemonic voices to represent themselves. Protestors chose to represent themselves through the manipulation of clothing and station (taking the title Lady, Captain, or Colonel) thus creating a space to both challenge and uphold traditional hierarchical society. Men dressed as women in skimmingtons and as Lady Skimmingtons to challenge royal and state dictates that directly impacted their lives. While cross-dressing, these men upheld tradition by using the long-held custom of skimmington; they did not try to be women while dressed as women. Women dressing as men challenged the gender hierarchy but did not try to eliminate it. Captain Dorothy fought against enclosure because it was not in her best interests but she did not campaign to retain her leadership status. Even in The Tamer Tamed, the women's sartorial subversion challenges the tradition of wife-taming but upholds basic conventions regarding marriage. The Western Rising, in its size and scale, took up greater concerns of gender, class, and the meaning of justice through multiple layers of inversion. The appearance of Lady Skimmington in forest protests provides insight into the nature of relationships between individuals, the community, and the state. The traditional intercommunity ritual of skimmington was extrapolated onto the larger stage of the western communities against the national community headed by court and king. The representation of men and women as anything other than the men or women they were born as became a powerful mechanism for challenging established notions of property and ownership. The identity attached to clothing and station became a battleground for the ownership of that identity - leader or criminal, man or woman, master or servant, landed or landless.

\section{Notes}

I Natalie Zemon Davis, Society and Culture in Early Modern France (Stanford, 1975), I47.

2 Karen Newman, Fashioning Femininity and English Renaissance Drama (Chicago, I99I), 28.

3 John Locke, The Second Vindication of the Reasonableness of Christianity (London, 1695). For examples of nineteenth-century skimmingtons including the Rebecca riots of the I840s see E.P. Thompson, Customs in Common: Studies in Traditional Popular 
Culture (New York, 1993), esp. 467-539, and Natalie Zemon Davis, 'Women on Top', Society and Culture in Early Modern France (Stanford, 1975), I24-5I.

4 Davis, Society and Culture in Early Modern France, I50.

5 David Underdown, 'The Taming of the Scold: the Enforcement of Patriarchal Authority in Early Modern England', Order and Disorder in Early Modern England, Anthony Fletcher and John Stevenson (eds) (Cambridge, 1987), II8.

6 Quoted in Laura Levine, Men in Women's Clothing Anti-theatricality and Effeminization, I579-I642 (Cambridge, 1994), 23.

7 David Cressy, 'Gender Trouble and Cross-Dressing in Early Modern England', The Journal of British Studies 35.4 (1996), 45I.

8 Marjorie Garber, Vested Interests: Cross-dressing and Cultural Anxiety (New York, 1997), 30.

9 Cressy, 'Gender Trouble', 453.

Io Martin Ingram, 'Ridings, Rough Music and the "Reform of Popular Culture", Past and Present I05 (1984), 99.

II For information on common rights and the impact of enclosure on community relations see Gregory and Anthony Clark, 'Common Rights to Land in England, I475I839', The Journal of Economic History 6I.4 (200I): I009-36; E.F. Gay, 'The Midland revolt and the inquisition of depopulation of 1607 ', Transactions of the Royal Historical Society, new series I8 (1905): 195-244; Christopher Hill, Liberty against the Law: Some Seventeenth-Century Controversies (New York, 1997); Roger Manning, Village Revolts: Social Protest and Popular Disturbances in England, I509-I640 (Oxford 2003).

I2 Jean Howard, 'Crossdressing, the Theatre, and Gender Struggle in Early Modern England', Shakespeare Quarterly 39.4 (1988), 421.

13 David Underdown, Revel, Riot, and Rebellion: Popular Politics and Culture in England I603-1660 (Oxford, 1985), II9.

I4 Garber, Vested Interests, 3I.

I5 Garber discusses change in law and the anxieties James voiced regarding 'mannish women'; Ibid, 3I-2.

I6 John Taylor, 'Superbia Flagellum, or the Whip of Pride', All the Works of John Taylor the Water-Poet (London, I630), I.42

17 John Taylor, 'The Very Old Man: or the Life of Thomas Parr,' Works of John Taylor the Water Poet (London, I630; rpt; New York, 1967), 7.19-20.

I8 In "Like the Old Robin Hood": "As You Like It" and the Enclosure Riots', Shakespeare Quarterly 43.I (1992). Richard Wilson argues that the related and devastating economic changes of enclosure, depopulation, and dearth provided a backdrop to several of Shakespeare's plays. He argues that As You Like It is a 'drama of enclosure 
and exclusion' and The Two Gentlemen of Verona connects 'outlawry with social displacement' from the depopulation wrought by enclosure.

I9 Dawson, 'Witchcraft/Bigamy', 86.

20 Thomas Heywood and Richard Brome, The Witches of Lancashire, Gabriel Egan (ed.) (New York, 2002), 4.3.174.

2I Helen Ostovich (ed.), The Late Lancashire Witches, in The Richard Brome Electronic Edition. Richard Cave (gen. ed.) (Sheffield, 2009).

22 Steven Hindle, 'Crime and Popular Protest', A Companion to Stuart Britain, Barry Coward (ed.) (Oxford, 2003), I39.

23 David Underdown, Revel, Riot, and Rebellion, Io9.

24 Buchanan Sharp, In Contempt of All Authority: Rural Artisans and Riot in the West of England I586-I660 (Berkeley, 1980), 94.

25 Roger Manning, Village Revolts: Social Protest and Popular Disturbances in England, I509-I640 (Clarendon, I988), 95.

26 Sharp, In Contempt of All Authority, 95.

27 Underdown, Revel, Riot, and Rebellion, iıo.

28 Wilson, "Like the Old Robin Hood", 2.

29 Sharp, In Contempt of All Authority, 96.

30 Ibid, 83.

3 I Ibid, 97.

32 John Rushworth, Historical Collections of Private Passages of State (London, I722), vol. 3, appendix 73 .

33 Sharp, In Contempt of All Authority, I03.

34 Ibid, I05-6.

35 Ibid, 98.

36 G.B. Harrison, A Jacobean Journal: Being a Record of those Things Most Talked of during the Years I603-1606 (London, 194I), 250.

37 William Lambarde, Eirenarcha or the Office of the Justice of Peace (1602), 169-70.

38 John Walter, 'Grain riots and popular attitudes to the law: Maldon and the crisis of I629', An Ungovernable People: The English and Their Law in the Seventeenth and Eighteenth Centuries, John Brewer and John Styles (eds) (New Brunswick, 1983), 63.

39 Davis, Society and Culture in Early Modern France, I47.

40 Ibid, I40-I.

4I Cressy, 'Gender Trouble', 452, provides examples of female transvestite characters who were rewarded for their cross-dressing. Howard discusses the increasingly harsh treatment of cross-dressed women by the law in 'Crossdressing', 424.

42 Howard, 'Crossdressing', 436. 
43 Andy Wood, “Poor Men Woll Speke One Daye": Plebian Languages of Deference and Defiance in England, c. 1520-1640' in The Politics of the Excluded, c. I500-1850, Tim Harris (ed.) (New York, 200I), 77.

44 John Fletcher, The Tamer Tamed; or The Woman's Prize (1609), Celia Daileader and Gary Taylor (eds) (New York, 2006), I.3.66.

45 Henry King, 'The Woes of Esay', in Minor Poets of the Caroline Period, G. Saintsbury (ed.) (Oxford, 1921), 3. 230.

46 Adam Moore, Bread for the poor and Advancement of the English Nation (London, I653), A2. 